\title{
Thematic groups of political neologisms in English and Ukrainian: a comparative approach
}

\author{
V. V. Hromovenko \\ International Humanitarian University \\ Corresponding author. E-mail: gromovenkovikkos@gmail.com, https://orcid.org/0000-0001-6706-3231
}

Paper received 09.02.20; Accepted for publication 22.02.20.

\begin{abstract}
https://doi.org/10.31174/SEND-Ph2020-218VIII66-06
\end{abstract}
\begin{abstract}
The article deals with the comparative analysis of political NEOLOGISMS from the perspective of their semantic organization. A political neologism is a lexical innovation that is a part of the system of socio-political vocabulary of the language. There have been distinguished four common thematic groups; they are State, Politics, Society, and Economy. The quantitative characteristics of these groups are of allomorphic character in the languages contrasted. The common group "State" is represented by a larger number of English neologisms, and the common group "Politics" is represented by most Ukrainian new words.

Keywords: political neologism, thematic group, meaning, seme, comparative analysis.
\end{abstract}

Introduction. The rapid development of different spheres of our life requires the designation of new objects and phenomena, as a result a large number of neologisms appears. There are different approaches to the definition of the term "neologism". It applies both to words or phrases that designate a new concept, subject, branch of science, etc., and to nominations that already exist in the language. Thus, a neologism may be defined as "a word created to describe a new object or express new concepts" [10]; as a newly created lexical unit or an existing lexical unit that has acquired a new meaning [21]. New words in the language are constantly entering the lexicon to describe new concepts and technologies" [18, p. 264].

Literature review. A political neologism is a lexical innovation that functions in political discourse and is a part of the system of socio-political vocabulary of a language. It models a particular vision of the object of nomination as determined by the intentions of the addressee. Political neologisms are connected thematically by the sphere of their usage. Any thematic groups include the words "not on the basis opposition to one another according to a particular trait, but on the basis of a common generic trait"[15, p. 178]. The thematic group is formed by combining the meanings of the word, on the basis of which further division of the common concept that belongs to the cognition category is built [14]. Words are grouped into thematic groups when there is a link between the objects of reality. Division of political neologisms into thematic groups is to some extent conditional, since concepts such as state and politics, politics and economy, etc., are closely intertwined. But that approach is justified due to the fact that there is a need to organize and systematize the actual lexical material.

The aim of the paper is to classify, describe and compare political neologisms from the point of view of their semantic organization and to draw common and divergent features of such groupings in English and Ukrainian.

Material and methods. The study of political neologisms is carried out from the point of view of their semantic structure taking into account the identification of the sphere of social and political life. Semantic characteristics of new words are clarified in the process of the semantic description of political neologisms, which reflect the structure of the meaning of individual lexical units [11, p. 87]. Classifications of neologisms [5, p. 126,] are based on a systematic approach to the study of vocabulary. The dictionary definitions of lexical units selected for the investigation are analyzed. Dictionary articles indicate the correspondence between a certain word and its meaning representation. Based on the definition of a dictionary article that names the semantic components of lexical meaning [6, p. 85], using logical analysis [11, p. 84,] it is possible to clarify the semantic structure of a word and its reference to a specific thematic group.

Meanings are interpreted as a set of components, combined in different ways. They are quite independent [11, p. 81]. This understanding enables us to explore the structure of meaning. Componential analysis serves this purpose playing a leading role in the description of lexical units [2, p. 113]. It appears as a reliable way of analyzing the structure and system of lexical meaning, a means of modeling the hierarchical semantic structure of the word [1, p. 198], as the procedure of splitting meaning into minimal semantic components $[11$, p. 81$]$, which is focused on distinguishing individual sememes, demonstrating specific relationships and relationships within the sememes [7, p. 115]. The latter helps to compare both common and distinct components of word meanings. Singling out nuclear elements (archisemes [4, p. 81] or integral semes [11, p. 82-83]) in the semantic structure of words is the basis for their integration within a thematic group, which is understood as a subject-logical category, reflecting the structure of the picture of the world and its individual fragments.

In the componential analysis semes are singled out, they are elementary units that form a hierarchical structure [1, p. 198], where the integral semes or archiseme are contrasted as a nuclear element of the seme structure. Such approach allows combining the words into a specific thematic group or into a lexical semantic field [11, p. 8283]. Differential semes make it possible to distinguish individual words.

Thematic groups are formed on the basis of the analysis of dictionary articles «politics», «політика», presented in explanatory dictionaries of English and Ukrainian. In particular, "politics» is characterized as "the activities of the government, members of law-making organizations, or people who try to influence the way a country is governed» [16], «the actions or activities concerned with achieving and using power in a country or society» [17], «the activities associated with the governance of a country or area, especially the debate between 
parties having power; the activities of governments concerning the political relations between states» [20]. The definitions offered in the explanatory dictionaries focus on the activities of government bodies and lawmakers, those who seek to influence the country's governance process and its relations with other states, and generally those related to governance of country or region, struggle for power. According to the explanatory dictionaries of the Ukrainian language, політика - загальний напрям, характер діяльності держави, певного класу або політичної партії; напрям діяльності держави або політичної партії в тій чи в тій галузі в певний період; подї й питання внутрішньодержавного та міжнародного суспільного життя [13, р. 80; 3, с. 1035]. The meaning of the lexeme політика has the following semes in its structure 'державна діяльність', 'діяльність політичної партії, 'внутрішньодержавне та міжнародне суспільне життя'.

Taking abovementioned into consideration it is possible to group political neologisms in such thematic groups: 'State', which encompasses words that describe public administration; "Politics", consisting of lexical units that characterize the activities of political parties and groups; "Society", which encompasses lexical units that describe the activities of public organizations and actors; "Econo$m y^{\prime \prime}$, which contains units that actualize the notion related to the economic component of government and innerstate life.

The following example demonstrates the semantic features of a neologism and its inclusion in a thematic group. The lexeme "narcissocracy" has the meaning of "government by the excessively self-centered" [22]; it is a telescope formed from the noun narcissist and the format ocracy. The semes 'control' and 'persons with exceptional self-esteem' are differentiated in the seme structure of the lexical unit. The presence of the seme 'control' is the basis for referring this neologism to the thematic group 'State'.

In addition to the dictionary definition, information about the word can be provided in the Internet resources. For example, the lexeme "astroturf" is presented as a "fake grass-roots-movement" [22]. This is explained in a quote from the "Petersburg Times» (Florida), May 29, 1998:

"Operators in the governor's office were suspicious when they got a rash of calls from people who were obviously being coached on what to say. When the operators pressed the callers, they said they were sugar cane workers who had been told that they would lose their jobs if the governor vetoed the bills. Chiles' aides called it an «Astroturf», or "fake grass-roots campaign» [22].

The example shows that the newspaper article provides the context for the use of the lexical unit, describes the situation that contributed to its appearance, explains the conditions of occurrence of the neologism. Graphic method of the use of quotation marks, in which both the lexical unit and its interpretation are indicated, signals that it is a neologism, and it is unfamiliar to the reader.

The following lexical unit "cap" [22] is marked as a transitive verb and a noun used in the sphere of politics. In the example under consideration, the lexeme acquires a new meaning though it is not new in the language. According to the definition, the verb cap means "impose a limit on (something)"; «specifically, of central government: to regulate the spending of (a local authority) by imposing an upper limit on local taxation» [22]. The specified lexical unit actualizes semes 'approval',' 'restrictions', 'regulations', local taxes',' central government ',' local authorities', enabling to refer the unit to the "State" thematic group. The lexeme describes the relationship between central and local governments, so it belongs to the "Government" subgroup.

The noun антикорупиійник is characterized as особа, яка провадить антикорупиійну діяльність [3, с. 16]. The semes 'особа', 'вид діяльності' are differentiated in the dictionary definition. To understand the meaning of the lexeme better, it is appropriate to consider its definition, корупиія - використання посадовою особою свого службового становища з метою особистого збагачення//підкупність, продажність урядовиів $i$ громадських діячів [12, p. 302.], which helps to clarify 'діяльність' as 'протидія використанню службового становища для особистого збагачення'. On this basis, the lexeme has been referred to the thematic group "State". In addition, the same word can be referred to the thematic group "Society", because, according to the explanatory dictionary, corruption as an activity can be applied to public figures.

The following lexical unit is веломайданівець - особа-учасник Веломайдану [8, p. 36] actualizes the seme 'особа-учасник', 'Велосипедний Майдан'. Instead, the lexemе веломайдан denotes protests [8, p. 36], connected with the use of bicycles. Against this background, the lexical unit веломайданівець has been referred to group «Суспільство», a subgroup of notions that characterize public life.

Thus, the componential analysis of the seme structure of neologisms serves as a basis for distinguishing semes in the structure of the studied units and referring them to a specific thematic group.

The quantitative characteristics of each group allowed defining the tendencies in neologism representation in English and Ukrainian, to determine the most productive ones.

Results and discussion. There are the following thematic groups of political neologisms in English and Ukrainian, which in their turn include several subgroups:

1. State: 1) government; 2) elections; 3) diplomatic activity; 4) military terminology.

2. Policy: 1) concepts that characterize national politics; 2) concepts related to aggressive politics; 3) concepts characterizing the activities of party, political and state leaders; 4) concepts characterizing interstate relations; 5) political terms; 6) the name of the parties.

3. Society: 1) concepts related to public life; 2) concepts characterizing negative phenomena in society.

4. Economy: 1) names of economic organizations, unions; 2) new economic terms.

The analysis showed that neologisms of the sociopolitical sphere, which entered the English and Ukrainian languages at the beginning of the 21 st century, are related to the mentioned four thematic groups. It is possible to claim that there is some similarity in the general picture regarding the distribution of neologisms in the two languages under consideration.

Table 1.1 shows that in English most neologisms appeared in the groups "State" and "Politics", in the Ukrain- 
ian language most of the new words appeared in the sphere of "Політика". In English, the group "Society" has a larger number of neologisms than in the Ukrainian language. There is an interesting fact that the number of new lexical units associated with government is approximately the same in both languages.

Table 1.1 The main thematic groups of political neologisms in English and Ukrainian

\begin{tabular}{|l|c|c|}
\hline \multirow{2}{*}{$\begin{array}{c}\text { Thematic } \\
\text { groups }\end{array}$} & \multicolumn{2}{|c|}{ Languages } \\
\cline { 2 - 3 } & English (\%) & Ukrainian (\%) \\
\hline State & 34,6 & 25,6 \\
\hline Politics & 34,3 & 43,7 \\
\hline Society & 25 & 21,5 \\
\hline Economy & 6,1 & 9,2 \\
\hline Total & 100 & 100 \\
\hline
\end{tabular}

In Table 1.2, a more detailed distribution of thematic subgroups in each language can be seen. The analysis enables us to conclude that English is more actively enriched by concepts related to public life.

Conclusions. Four thematic groups of political neologisms have been singled out. They are characterized by both isomorphic and allomorphic features. In English, most neologisms appeared in the groups "State" and "Politics", in the Ukrainian language most of the new words appeared in the sphere of "Politics". There are more English than Ukrainian neologisms in the group 'Society'. The number of new lexical units associated with government is approximately the same in the languages under consideration. There has been marked an increasing tendency in English to use new words to denote notions re- lated to public life. The further perspective of the research lies in the possibility to study the functioning of the vocabulary in question in political discourse in the limelight of the pragmatic and communicative approaches.

Table 1.2 Comparative analysis of thematic subgroups of political neologisms in English and Ukrainian

\begin{tabular}{|c|c|c|c|c|}
\hline \multirow{2}{*}{$\begin{array}{l}\text { № } \\
\text { № }\end{array}$} & \multicolumn{2}{|c|}{ Thematic subgroups } & \multirow[t]{2}{*}{\begin{tabular}{|l|} 
English \\
$(\%)$
\end{tabular}} & \multirow[t]{2}{*}{$\begin{array}{l}\text { Ukrainian } \\
(\%)\end{array}$} \\
\hline & & State & & \\
\hline 1 & Government & & 14,8 & 18,6 \\
\hline 2 & \multicolumn{2}{|l|}{ elections } & 11 & 4,5 \\
\hline 3 & \multicolumn{2}{|c|}{ diplomatic activity } & 2 & 0,7 \\
\hline \multirow[t]{2}{*}{4} & \multicolumn{2}{|c|}{ military terminology } & 6,5 & 1,8 \\
\hline & & Politics & & \\
\hline 5 & \multicolumn{2}{|c|}{ Ha national politics } & 10,2 & 19,5 \\
\hline 6 & \multicolumn{2}{|c|}{$\begin{array}{l}\text { concepts related to aggressive poli- } \\
\text { tics }\end{array}$} & 8,1 & 6,2 \\
\hline 7 & \multicolumn{2}{|c|}{$\begin{array}{l}\text { concepts characterizing the activities } \\
\text { of party, political and state leaders }\end{array}$} & 6 & 8,1 \\
\hline 8 & \multicolumn{2}{|c|}{$\begin{array}{l}\text { concepts characterizing interstate } \\
\text { relations }\end{array}$} & 1 & 0,9 \\
\hline 9 & \multicolumn{2}{|c|}{ political terms } & 6 & 5 \\
\hline \multirow[t]{2}{*}{10} & \multicolumn{2}{|c|}{ name of parties } & 3 & 4 \\
\hline & \multicolumn{2}{|c|}{ Society } & & \\
\hline 11 & concepts rela & to public life & 15,3 & 9,2 \\
\hline \multirow[t]{3}{*}{12} & \multirow{2}{*}{\multicolumn{2}{|c|}{$\begin{array}{l}\text { concepts characterizing negative } \\
\text { phenomena in society }\end{array}$}} & 9 & 12,3 \\
\hline & & & & \\
\hline & \multicolumn{2}{|c|}{ Economy } & & \\
\hline 13 & \multicolumn{2}{|c|}{$\begin{array}{l}\text { names of economic organizations, } \\
\text { unions }\end{array}$} & 1,1 & 2,3 \\
\hline 14 & \multicolumn{2}{|c|}{ new economic terms } & 5 & 6,9 \\
\hline \multicolumn{3}{|c|}{ Total } & 100 & 100 \\
\hline
\end{tabular}

\section{ЛІТЕРАТУРА}

1. Алефиренко Н. Ф. Спорные проблемы семантики: монография. Москва: Гнозис, 2005. 326 с.

2. Апресян Ю. Д. Современные методы изучения значений и некоторые проблемы структурной лингвистики. Проблемы структурной лингвистики. Москва: Наука, 1963. C. $102-149$.

3. Великий тлумачний словник сучасної української мови (з дод. і допов.)/Уклад. і голов. ред. В.Т. Бусел. К.; Ірпінь: ВТФ «Перун», 2005. 1728 с.

4. Гак В. Г. Семантическая структура слова как компонент семантической структуры высказывания. Семантическая структура слова. Москва: Наука, 1971. С. 78-96.

5. Кронгауз М. А. Семантика: учебник для вузов. Москва: Рос. гос. гуманит. ун-т, 2001. 399 с.

6. Кузнецов А. М. От компонентного анализа к компонентному синтезу. Москва: Наука, 1986. 127 с.

7. Левицкий В. В. Семасиология: монография для молодых исследователей. Изд. 2, исправл. и дополн. Винница: Нова Книга, 2012. 680 с.

8. Нелюба А., Редько Є. Лексико-словотвірні інновації (2015-2016). Словник/Загальна редакція А. Нелюби. - Х.: Харківське історико-філологічне товариство, 2017. - 204 c.

9. Покровский М. М. Семасиологические исследования в области древних языков. Избр. работы по языкознанию. Москва: Изд-во АН СССР, 1959. С. 80-94.

10. Розенталь Д.Э., М.А. Теленкова Словарь-справочник лингвистических терминов. М.: Просвещение, 1985. 399с.

11. Селиверстова О. Н. Труды по семантике. Москва: Языки славянской культуры, 2004. 960 с.
12. Словник української мови: [в 11 т.]/АН Української РСР, Ін-т мовознав. ім. О. О. Потебні; редкол.: І. К. Білодід (голова) [та ін.]. Київ: Наук. думка, Т. 4: I-М/ред. тому: А. А. Бурячок, П. П. Доценко. 1973. 840 с.

13. Словник української мови: [в 11 т.]/АН Української РСР, Ін-т мовознав. ім. О. О. Потебні; редкол.: І. К. Білодід (голова) [та ін.]. Київ: Наук. думка, Т. 7: ПоїхатиПриробляти. 1976. $723 \mathrm{c}$

14. Соколовская Ж. П. Система в лексической семантике (анализ семантической структуры слова) - К.: Вища школа, 1979. 192 с.

15. Шмелев Д. Н. Проблемы семантического анализа лексики: на материале русского языка. Москва: Наука, 1973. $280 \mathrm{c}$.

16. Cambridge Free English Dictionary and Thesaurus. URL: https://dictionary.cambridge.org/dictionary.

17. Collins Free Online Dictionary. URL: https://www.collinsdictionary.com.

18. Crystal D. (1992). An Encyclocpedic Dictionary of Language and Languages. Oxford: Oxford University Press

19. Katermina V. V. (2017). Linguocultural Characteristics of English Mass-Media Neologisms. US-China Foreign Language.Volume 15, Number 10, October 2017 (Serial Number 169). PP. 617-624.

20. Lexico.com: English Dictionary, Thesaurus, \& Grammar Help. URL: https://www.lexico.com.

21. Newmark P. About Translation. Clevedon:Multilingual Matters. $1992.184 \mathrm{p}$.

22. Word Spy. URL: https://www.wordspy.com. 


\section{REFERENCES}

1. Alefirenko N. F. Disputable issues of semantics: monograph. Moscow: Gnosis, 2005. 326 p.

2. Apresyan Yu. D. Present-day methods of studying the meaning and some issues of structural linguistics. Issues of Structural Linguistics. Moscow: Nauka, 1963. P. 102-149.

3. Great Explanatory Dictionary of Modern Ukrainian (ed. V.T. Busel). K.; Irpin: VTF «Perun», 2005. 1728 p.

4. Gak V. G. Semantic structure of the word as a component of the semantic structure of the utterance. Semantic structure of the word. Moscow: Nauka, 1971. CP 78-96.

5. Krongaus M. A. Semantics. Moscow: Ros. gos. humanit. universitet, 2001. $399 \mathrm{p}$.

6. Kusnetzov A. M. From componential analysis towards componential synthesis. Moscow: Nauka, 1986. $127 \mathrm{c}$.

7. Levitsky V. V. Semasiology. Vinnitsa: Nova Knyha, 2012. $680 \mathrm{p}$.

8. Nelyuba A., Redko E. Lexical and word-formation innovations (2015-2016). Dictionary (ed. A. Nelyuba. - Kh.: Kharkivske istoryko-filologichne tovarystvo, 2017. - 204 p.
9. Pokrovsky M. M. Semasiological investigations in the field of ancient languages. Selected works in Linguistics. Moscow: Izdatelstvo AN SSSE, 1959. P. 80-94.

10. Rozental D.E., Telenkova M.A. Dictionary of linguistic terms. M.: Prosveshchenie, 1985. 399p.

11. Seliverstova O. N. Works on Semantics. Moscow: Yazyki slavyanskoi kultury, 2004. $960 \mathrm{p}$.

12. Dictionary of the Ukrainian Language: [in 11 volumes] (general ed. I. K. Bilodid, etc.). Kyiv: Naukova Dumka, V. 4: IM (editor of the volume: A. A. Buryachok, P. P. Dotsenko. 1973. $840 \mathrm{p}$.

13. Dictionary of the Ukrainian Language: [in 11 volumes] (general ed. I. K. Bilodid, etc.). Kyiv: Naukova Dumka, V. 7: Поїхати-Приробляти. 1976. 723 р.

14. Sokolovskaya Zh. P. System in the lexical semantics (analysis of the semantic structure of the word) - K.: Vyshcha shkola, 1979. $192 \mathrm{c}$.

15. Shmelev D. N. Issues of the semantic analysis of lexemes: on the Material of the Russian language. Moscow: Nauka, 1973. $280 \mathrm{c}$.

22. Word Spy. URL: https://www.wordspy.com. 